\title{
Nicotinic acetylcholine receptors: Diversity and physiological importance for neurodegenerative disorders and development of organophosphate antidotes
}

\author{
ANTONIO ZANDONA \\ MAJA KATALINIĆ \\ Institute for Medical Research and Occupational \\ Health, POB 291, HR-10001 Zagreb, Croatia \\ *Corresponding author: \\ Antonio Zandona \\ azandona@imi.hr \\ Keywords: cholinergic; subunits; nAChR; nicotine; \\ AChE, Alzheimer's; Parkinson's

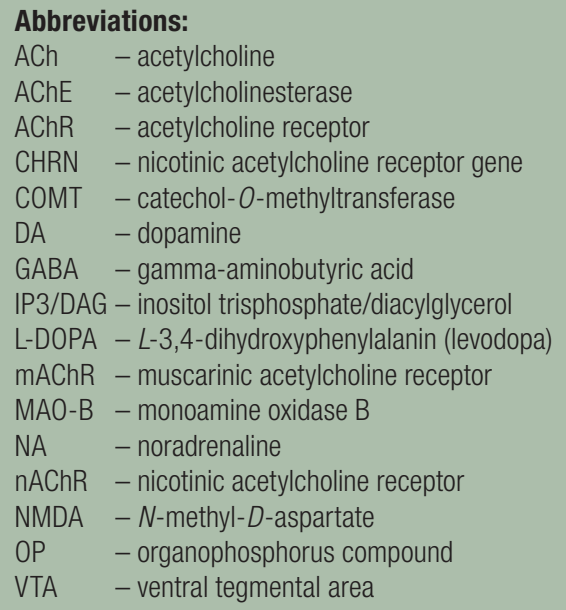

\begin{abstract}
The communication between the nervous and other systems in the organism is carried out by the transmission of nerve impulses. Diverse neurotransmitters are released into the synaptic cleft and bind to the specific receptors at the neighbouring cell to transmit the signal further. One of such receptors are nicotinic acetylcholine receptors ( $n A C h R$ ), integrated membrane proteins (ligand-gated ion channels) activated by the binding of a neurotransmitter acetylcholine. nAChR's main characteristic is their diversity, as they consist of five of the same or mutually different subunits, which contribute to the specific receptors properties and biological activity. During the assembly of a pentameric protein structure, various combinations of subunits are linked together. After the discovery of nAChR's involvement in various diseases, they became an important therapeutic target, for example in the treatment of neurodegenerative diseases (Alzheimer's and Parkinson's) and in the treatment of organophosphorus compound poisoning. This paper presents an overview of current knowledge on nicotinic receptors and an accompanying discussion on diseases, poisonings, potential drugs and treatments is given.
\end{abstract}

\section{INTRODUCTION}

$\mathbf{B}^{y}$ studying nicotine at the turn of the $20^{\text {th }}$ century, the concept of $\mathrm{B}_{\text {receptive substance was set up, from which the idea of a receptor was }}$ developed (1). A crucial event in nicotinic receptor studies was the chemical identification of the first neurotransmitter receptor. Successful identification allowed for further metabolic, pharmacological and biochemical research (2). Nicotinic acetylcholine receptors (nAChRs) are proteins integrated into membranes and belong to the superfamily of ligand-gated ion-channels $(3,4)$. Since they are formed by a specific combination of five subunits, there are different subtypes of nAChRs that mediate different physiological functions (5). Nicotinic receptors are expressed in the peripheral nervous system (PNS), where they mediate the transmission of impulses between nerve and muscle cells; in the central nervous system (CNS) and in other types of cells (keratinocytes, epithelial cells, macrophages, etc.; (5)). After understanding that the subtypes of nAChR contributed to the neuropathology of many diseases, there arose an interest in the development of therapeutic nicotine agonists and other drugs for specific subtypes and the use of cloned $\mathrm{nAChR}$ subunits as possible therapeutic agents (1). nAChRs have be- 
come an important therapeutic targets for the treatment of neurodegenerative diseases, primarily Alzheimer's and Parkinson's (5), but also in the treatment of poisoning with highly toxic organophosphorus compounds (6).

\section{Historical overview}

After studying nerve-muscle preparations, John Newport Langley found that muscle tissue possesses something that mixed with nicotine and curare (reversible inhibitor of $\mathrm{nAChR}$ ) receives stimulus and transfers it to other cells (7). In the 1960s, David Nachmansohn and other scientists identified the receptor for acetylcholine (ACh) in the electric eel (Electrophus electricus) electric organ by radioactive ligands, which was unusually rich in nicotinic synapses (8). In addition, Chen-Yuan Lee with snake venom, $\alpha$-bungarotoxin $(\alpha$-Bgt), specifically inhibited in vivo nerve-muscle transmission without interaction with acetylcholinesterase (AChE, EC 3.1.1.7, an enzyme that hydrolyses the ACh neurotransmitter in synapses). It has been shown that $\mathrm{nAChR}$ is a hydrophobic protein of high molecular weight and can be physically separated from AChE, and studies then confirmed that AChE and $\mathrm{nAChR}$ are different protein entities (9). In 1972, significant influence on the investigation of nicotinic acetylcholine receptors was the isolation of the new generation of $\mathrm{nAChR}$ from homogenates of marbled electric ray (Torpedo marmorata) (10). In 1973, the purified protein $\mathrm{nAChR}$ was observed under a microscope and rings-like structures (with a hydrophilic core linked to compact clusters) were detected. Such a compact cluster was made up of several subunits (11). A group of scientists in 1988 was able to generate $3 \mathrm{D}$ crystals of Torpedo nAChR for the first time $(12,13)$. Soon thereafter, the physiology and a variety of nicotinic receptors expression in the vertebrates was determined, including five different subunits that could be assembled in different ratios (14). Also, in the 1990s, nicotinic receptors and nicotine were associated with various diseases, such as schizophrenia (15), Alzheimer's (16), Parkinson's disease (17) and Tourette's syndrome (18) and research took a turn toward finding drugs and effective therapies for $\mathrm{nAChR}$-related states. In association with various diseases, the effect of organophosphorus compounds (OP) on the cholinergic system was also observed $(6,19)$. More precisely, the symptoms of OP poisoning are caused by the irreversible inhibition of the enzyme AChE, which leads to the accumulation of
ACh and extensive receptor stimulation (20, 21). In addition to the inhibition of AChE, several organophosphorus compounds directly affect the receptors of the cholinergic system and modulate the level of their receptor expression $(22,23)$. OPs thus also affect nicotine receptors, block the opening of the ion channel and desensitize the receptors (24-27).

\section{Acetylcholine receptors and nerve effects}

In general, acetylcholine receptors (AChR) are integrated membrane proteins, which are activated by neurotransmitter ACh binding. There are two types of such receptors: ionotropic nicotinic receptors ( $\mathrm{nAChRs),} \mathrm{which}$ exist in two forms (nervous and muscular), and five types of metabotropic muscarinic receptors (mAChR) M1 to M5, which can be classified into two traditional pharmacological groups: M1 and M2 receptors. The M1 group receptors (M1 and M3) interact via the IP3/DAG system (by activating phospholipase $\mathrm{C}$ ), inactivate $\mathrm{K}^{+}$channels, while M2 (M2, M4 and M5) receptors regulate adenylyl cyclase (intracellular cAMP concentration) and activate $\mathrm{K}^{+}$channels $(28,29)$. Like other transmembrane receptors, AChRs are classified according to their pharmacology or affinity and sensitivity to different compounds (Figure 1). Although all acetylcholine receptors, by definition, are sensitive to acetylcholine, they also react to other xenobiotics. For example, $\mathrm{mAChRs}$ are sensitive to muscarine $(30,31)$.

nAChRs are ionic channels for $\mathrm{Na}^{+}, \mathrm{K}^{+}$and $\mathrm{Ca}^{2+}$ and are particularly sensitive to nicotine. They are found in the central and peripheral nervous system, muscle and many other tissues (32). In the nerve-muscle synapse, they are the primary receptors for communication with the muscles and controlling muscle contraction. In this way, the peripheral nervous system transmits outgoing signals from presynaptic to postsynaptic cells within the sympathetic and parasympathetic nervous system. In the immune system, nAChRs regulate inflammatory processes and participate in signalling different intracellular pathways $(1,33,34)$.

Full activation of a postsynaptic nAChR occurs when two molecules of the neurotransmitter $\mathrm{ACh}$ are bound to it. The cationic channel of the receptor is opened because of the electrochemical gradients through which $\mathrm{Na}^{+}$and
A<smiles>CC(=O)OC[N+](C)(C)C</smiles>

B<smiles>CN1CCCC1c1cccnc1</smiles>

C

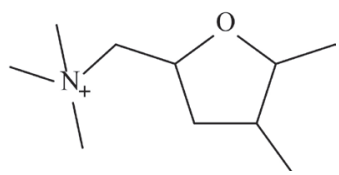

Fig. 1. Structures: $(A)$ acetylcholine, $(B)$ nicotine and $(C)$ muscarine 
$\mathrm{K}^{+}$flow. Every second a nerve vesicle releases neurotransmitters into the synapse. In addition to the acetylcholine receptors, there are many AChEs in the synapses, whose task is to hydrolyse the $\mathrm{ACh}$, thus terminating the signalling (35). The long-term binding of ACh to the receptor results in desensitization and thus inactivation of the ion channel. For example, irreversible AChE inhibitors lead to the accumulation of $\mathrm{ACh}$ in a synapse $(36,37)$, and one molecule of ACh can stimulate a few additional openings of ion channels. This may also have its advantages; like in diseases where the number of $\mathrm{nAChR}$ is reduced and causes muscular weakness, AChE-inhibiting drugs enable signal reactivation with the same neurotransmitter molecule, thereby improving signalling and replacing the lack of receptors $(38,39)$.

\section{Types, localization and receptor structure}

It has already been mentioned that $\mathrm{nAChRs}$ are ligand-gated ion channels forming pores on a cell plasma membrane mediating fast signal transmission through synapses. They are involved in a wide range of physiological processes and are divided into two groups: nerve and muscle (40). Muscle nAChRs are localized in the nervemuscle synapses, where the electrical nerve impulse signals contraction to the muscle cells and is responsible for muscle activity. Many different types of nerve $\mathrm{nAChR}$ are localized in synapses on postsynaptic nerve cells, as in the CNS, where they are involved in cognitive functions, learning, memory, etc. nAChR activation causes cation movement through the ion channel pore with the calcium ions which affect the release of neurotransmitters $(1,41)$.
Table 1. nAChR subunits subfamilies based on similarities in protein sequence (42)

\begin{tabular}{|llll|}
\hline Subfamily & Subtype & Type & Subunits \\
\hline I & & Neuronal & $\alpha 9, \alpha 10$ \\
II & & Neuronal & $\alpha 7, \alpha 8$ \\
III & 1 & Neuronal & $\alpha 2, \alpha 3, \alpha 4, \alpha 6$ \\
& 2 & Neuronal & $\beta 2, \beta 4$ \\
& 3 & Neuronal & $\beta 3, \alpha 5$ \\
IV & & Muscle & $\alpha 1, \beta 1, \delta, \gamma, \varepsilon$ \\
\hline
\end{tabular}

Studies revealed the existence of 5 different types of $\mathrm{nAChR}$ subunits with small molecular weight differences. Thus, $\mathrm{nAChR}$ consists of five subunit types: alpha $(\alpha 1-$ $\alpha 10)$, beta $(\beta 2-\beta 5)$, gama $(\gamma)$ delta $(\delta)$ and epsilon $(\varepsilon)$; found in various combinations. The nAChR subunits have been grouped into 4 subfamilies (I-IV) based on similarities in protein sequence, and subfamily III has been further divided into 3 subtypes (Table 1) (42). The most widely expressed nAChR subtypes are $\alpha 4, \alpha 7$ and $\beta 2$ (43). Nerve $\mathrm{nAChRs}$ are assembled just from alpha and beta units, while muscle $\mathrm{nAChR}$ from all five subunit types $(41,44)$.

Nicotinic receptors are always pentamers (Figure 2), with subunits disposed symmetrically in a circle around the central receptor channel pore. The receptors always contain two or more $\alpha$-subunits, which are crucial for ACh binding $(45,46)$. The ACh binding site is formed
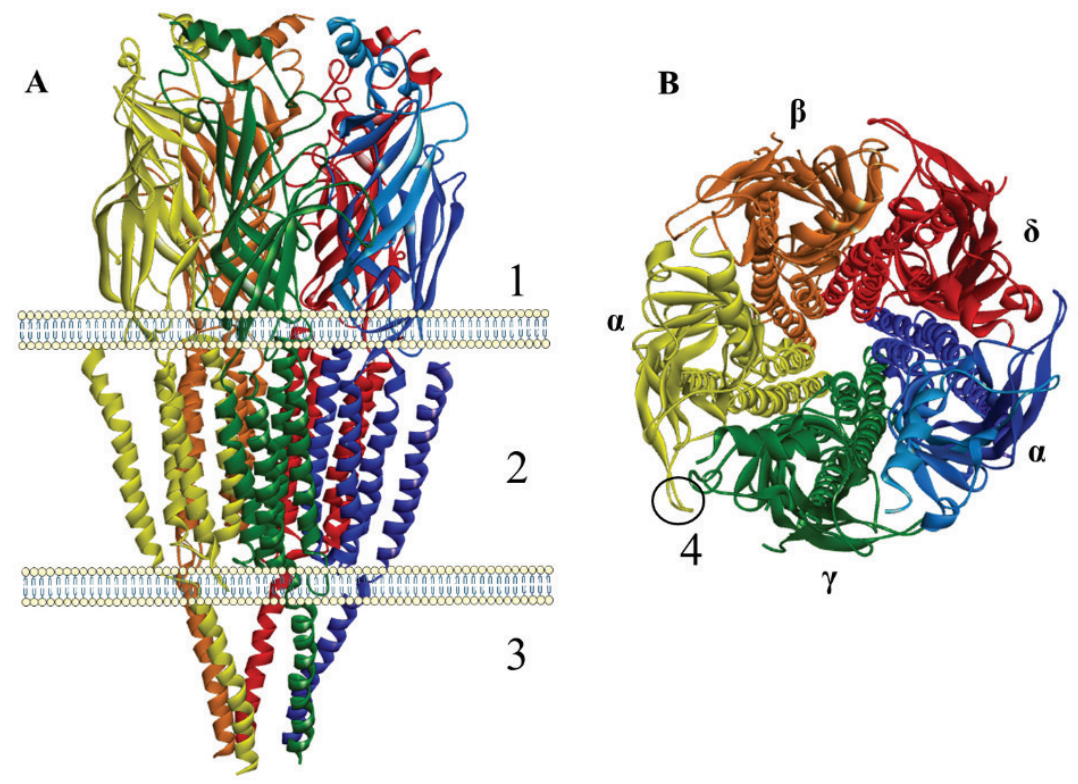

Figure 2. The basic structure of nicotinic acetylcholine receptors. (A) Torpedo marmorata $n A C h R$ structure (model from PDB code 2BG9; 49) with extracellular (1), transmembrane (2) and intracellular (3) domains, (B) the receptor is formed from 5 subunits around the central pore with Cys-loop (4) in a subunit. 
when dimers of $\alpha$-subunits and adjacent subunits associate $(47,48)$.

Nerve $\mathrm{nAChRs}$ are divided into two main groups based on their sensitivity to the snake venom $\alpha$-bungarotoxin. $\alpha$-Bungarotoxin-sensitive receptors are homomers ( $\alpha 7$ and $\alpha 9$ ), while $\alpha$-bungarotoxin-non-susceptible receptors are heteromeric (other subunits types). Most $\mathrm{nAChRs}$ are asymmetric heteromers in which neither ACh binding sites nor subunit-subunit interactions are identical $(48,49)$.

After years of experiments, the nicotinic receptor localization and structure, which contains the extracellular synaptic domain, four transmembrane $\alpha$-helix and the intracellular cytoplasmic domain, have been proposed (Figure 2). Further analysis revealed the existence of socalled Cys-loops in $\mathrm{nAChR}$ structure $(2,47)$. $\mathrm{nAChR}$ is also a glycosylated protein and has $\mathrm{N}$-linked glycosylation sites which vary depending on the subunits. A cys-cys pair is required for agonist binding and its presence denotes the existence of an $\alpha$-subunit $(41,47)$. A Cys-loop is characteristic for this type of receptor and in mammals these cysteines are most often separated with 13 conserved amino acids. Other receptors that belong to the same receptor superfamily as nAChR include: 5-hydroxytryptamine (5HT3), $\gamma$-aminobutyric acid type $\mathrm{A}\left(\mathrm{GABA}_{\mathrm{A}}\right)$ and $\mathrm{GABA}_{\mathrm{C}}$, glycine receptors, glutamate and histidine receptors (50).

\section{The variety of nicotine subunits}

The diversity of $\mathrm{nAChR}$ subunits is the main feature of the specific properties and functions of mature receptors. Receptor pentamers can be assembled from various combinations of $\alpha, \beta$ and other structural subunits (38, 41). Nowadays, 16 genes encoding for $\mathrm{nAChR}$ subunits are known, named CHRNA1-10 for $\alpha$ subunits, CHRNB1-4 for $\beta$ subunits, CHRNG, CHRND and $C H R N E$ for $\gamma, \delta$ and $\varepsilon$, respectively $(1,52,53)$. Different $\mathrm{nAChR}$ gene details are presented in Table 1. Mutations in $C H R N$ genes (causing loss or gain of $\mathrm{nAChR}$ function, increased or decreased sensitivity to ACh or desensibilisation of the $\mathrm{nAChR}$ ) can cause phenotypes with different manifestations such as congenital myasthenic syndrome, nocturnal frontal lobe epilepsy and multiple pterygiums (54-56). The genes CHRNA3/CHRNA5/CHRNB4 or CHRNB3/CHRNA6 are in gene clusters on chromosomes $15 \mathrm{q} 25$ or $8 \mathrm{p} 11$, respectively; while other $C H R N$ genes are separately located on chromosomes 1, 2, 4, 8, 11, 15, 17 or 20 as shown in Table 2.

In some brain areas, diverse specific subtype subunits participate in order to form an $\mathrm{nAChR}$ of high affinity for substrates. In the basal ganglia, including the ventral tegmental area (VTA) and substantia nigra, the $\alpha 6$ and $\beta 3$ $\mathrm{nAChR}$ subunits were included in $\alpha 4 \beta 2 \mathrm{nAChR}$ complexes to create a high affinity receptor for ACh (Table 3). Currently, these are the only areas in the brain where $\alpha 6$ and $\beta 3$ subunits are co-expressed alongside the $\alpha 4$ subunit, which is very important for the appearance and therapy of Parkinson's disease (57). The autonomic nervous system is characterized by an abundant expression of $\alpha 3$ and $\beta 4 \mathrm{nAChR}$, while expression of $\alpha 4$ and $\beta 2$ subunits dominates the central nervous system. In example, coordinated expression of essential subunits is strongly regulated in the brain during the development of the organism and during various injuries (58).

Table 2. nAChR genes: subunit receptor name, gene names, chromosomal location, gene length (kb), gene cluster (if applicable), and number of aminoacids $(A A)$ in expressed protein $(1,52)$

\begin{tabular}{|c|c|c|c|c|c|}
\hline Subunit receptor & Gene name & Chromosome & Gene (kb) & Gene cluster & Protein (AA) \\
\hline$\alpha 1$ & CHRNA1 & $2 \mathrm{q} 31.1$ & 16.64 & & 482 \\
\hline$\alpha 2$ & CHRNA2 & $8 \mathrm{p} 21.2$ & 18.51 & & 529 \\
\hline$\alpha 3$ & CHRNA3 & $15 \mathrm{q} 25.1$ & 28.24 & $C H R A 3-A 5-B 4$ & 622 \\
\hline$\alpha 4$ & CHRNA4 & $20 q 13.33$ & 14.75 & & 627 \\
\hline$\alpha 5$ & CHRNA5 & $15 \mathrm{q} 25.1$ & 29.71 & $C H R A 3-A 5-B 4$ & 515 \\
\hline$\alpha 6$ & CHRNAG & $8 \mathrm{p} 11.21$ & 15.93 & CHRNB3-A6 & 494 \\
\hline$\alpha 7$ & CHRNA7 & $15 \mathrm{q} 13.2$ & 142.25 & & 534 \\
\hline$\alpha 9$ & CHRNA9 & 4p14 & 19.63 & & 479 \\
\hline$\alpha 10$ & CHRNA10 & $11 \mathrm{p} 15.4$ & 5.8 & & 450 \\
\hline$\beta 1$ & CHRNB1 & $17 \mathrm{p} 13.1$ & 12.65 & & 501 \\
\hline$\beta 2$ & CHRNB2 & $1 \mathrm{q} 21.3$ & 12.25 & & 502 \\
\hline$\beta 3$ & CHRNB3 & $8 p 11.21$ & 39.99 & CHRNB3-A6 & 458 \\
\hline$\beta 4$ & CHRNB4 & $15 \mathrm{q} 25.1$ & 17.48 & CHRA3-A5-B4 & 498 \\
\hline$\delta$ & CHRND & $2 \mathrm{q} 37.1$ & 10.48 & & 517 \\
\hline$\gamma$ & CHRNG & $2 \mathrm{q} 37.1$ & 6.6 & & 517 \\
\hline$\varepsilon$ & CHRNE & $17 \mathrm{p} 13.2$ & 5.3 & & 496 \\
\hline
\end{tabular}


Table 3. The presence of different $\alpha$ and $\beta$ subunits in certain parts of the brain (*specific subtype; - not determined) (62).

\begin{tabular}{|lll|}
\hline Localization & Type nAChR & Involved in specific neurotransmitter release \\
\hline Amygdala & $\alpha 4 \beta 2, \alpha 7$ & - \\
Cerebellum & $\alpha 4 \beta 2, \alpha 7, \alpha 3 \beta 3^{*}, \alpha 3 \beta 4^{*}$ & Glu \\
Cortex & $\alpha 4 \beta 2, \alpha 4 \alpha 5 \beta 2, \alpha 7$ & Glu, ACh, DA \\
Hedial habenula & $\alpha 4 \beta 2, \alpha 3 \beta 2^{*}, \alpha 7, \alpha 3 \beta 3 \beta 4, \alpha 3 \beta 4^{*}$ & - \\
Hippocampus & $\alpha 4 \beta 2, \alpha 4 \alpha 5 \beta 2, \alpha 3 \beta 4, \alpha 7$ & Glu, ACh, DA \\
Hypothalamus & $\alpha 4 \beta 2, \alpha 7$ & NA \\
Interpeduncular nucleus & $\alpha 4 \beta 2^{*}, \alpha 7, \alpha 3 \beta 3 \beta 4, \alpha 3 \beta 4, \alpha 2 \beta 2^{*}$ & ACh, GABA, NA \\
Locus coeruleus & $\alpha 3 \beta 4, \alpha 6 \beta 2 \beta 3^{*}$ & - \\
Olfactor bulb & $\alpha 4 \beta 2, \alpha 7$ & Glu, DA \\
Pineal gland & $\alpha 3 \beta 4, \alpha 7$ & - \\
Rapche nuclei & $\alpha 4 \beta 2$ & - \\
Spinal cord & $\alpha 4 \beta 2, \alpha 7, \alpha 3 \beta 2^{*}$ & - \\
Striatum & $\alpha 4 \beta 2, \alpha 4 \alpha 5 \beta 2, \alpha 6 \beta 2 \beta 3, \alpha 6 \alpha 4 \beta 2 \beta 3$ & Glu, DA \\
Substantia nigra, VTA & $\alpha 4 \beta 2, \alpha 4 \alpha 5 \beta 2, \alpha 7, \alpha 3 \beta 4^{*}, \alpha 6 \beta 2 \beta 3$ & - \\
Thalamus & $\alpha 4 \beta 2, \alpha 4 \alpha 5 \beta 2$ & DA, GABA \\
\hline
\end{tabular}

$\alpha 7$ are the most researched subunits of all known nicotinic subunits types. Receptors assembled of $\alpha 7$ subunits have a high $\mathrm{Ca}^{2+}: \mathrm{Na}^{+}$bandwidth ratio (59). As a result, the opening of the $\alpha 7 \mathrm{nAChR}$ channel may cause several $\mathrm{Ca}^{2+}$-dependent mechanisms, including the activation of secondary signal pathways (60). Co-expression and assembly, i.e. binding of the $\alpha 7 \mathrm{nAChR}$ subunit to other subunits, affects receptor ionic permeability, so $\mathrm{nAChR}$ consisting of $\alpha 7$ and $\beta 2$ subunits has pharmacological properties different from those homozygous $\alpha 7$ nAChR (61).

Pentameric structures, unlike those with pair subunits structures (e.g., tetramers), require multiple mechanisms for overcoming problems related to receptor assembly. Coordination of regulatory mechanisms between transcription and receptors assembly, which respond to external changes, are a common biological feature of nicotinic receptors. The first level of regulation of the region-specific expression of $\mathrm{nAChR}$ is transcriptional control of subunit expression.

Posttranslational modifications are crucial for the regulation of mature receptor functions, their expression and localization. There are several checkpoints in the cell to ensure proper assembly. Experiments with the chimeric recombinant subunits showed that the 23-amino acid region (from G23 to D46) contains the residues needed for proper $\alpha 7$ subunit assembly to the homopentamer receptors and a Cys-loop is needed for proper domain folding (63). Another significant control point for $\mathrm{nAChR}$ is the endoplasmic reticulum where degradation of proteins is an important part of regulating receptor concentration. In total, $80 \%$ of the synthesized subunits are mproperly assembled and never leave the endoplasmic reticulum, where they are degraded (64). Reduction of the degradation of precursor subunits in the endoplasmic reticulum results in increased concentration of $\mathrm{nAChR}$ on the cell membrane (65). Also, continuous nicotine exposure increases the concentration of $\mathrm{nAChR}$ on the surface of the cell by reduction of the degradation of the intracellular pool of receptors (66). Another important posttranslational regulation is the modification achieved by $\mathrm{N}$ glycosylation, where more sites in the $\mathrm{NH}_{2}$-terminal domain of the $\mathrm{nAChR}$ subunit are glycosylated. It has been found that muscular nAChR glycosylation is not required for receptor assembly or the formation and functioning of Cys-loops (67). Still, proper glycosylation is necessary for their subsequent incorporation into the plasma membrane $(68,69)$. In addition, palmitoylation and phosphorylation are also mechanisms that regulate the expression, receptor function and binding efficacy of different nAChR subunits. Palmitoylation is a reversible posttranslational modification where the palmitate covalently binds to Cys residues in the endoplasmic reticulum (70, 71). As opposed to that, in phosphorylation, phosphate binds to specific residues within the cytoplasmic domain (72). Besides, as mentioned nicotinic receptors also possess the ability of increasing upregulation when exposed to high nicotine concentrations; still, some subtypes have a lower level of expression (73).

\section{Insight into the function of $n A C h R$}

Activation of mammalian nerve $\mathrm{nAChR}$ promotes the opening of an unselected cationic channel leading to $\mathrm{Na}^{+}$ flow, depolarization of the membrane and activation of $\mathrm{Ca}^{2+}$ channels (49). $\mathrm{Ca}^{2+}$ flow through $\mathrm{nAChR}$ or voltagegated channels is essential for nicotine modulation, synaptic plasticity, nerve viability, differentiation and migra- 
tion. In the nervous system expressing specific nAChR subtypes, nicotine mediates activation of several $\mathrm{Ca}^{2+}$ independent kinases including $\mathrm{PI} 3 \mathrm{~K}$, protein kinase $\mathrm{C}$ (PKC), protein kinase A (PKA) and extracellular signalregulatory kinase $(\mathrm{ERK})(74,75)$. Also these kinases activate a large number of transcription factors by downstream regulation, such as cAMP-binding protein (CREB) that further activates transcription factor 2 (ATF-2) (76) and the ETS-like transcription factor (Elk1), and transcript signal transducer (STAT3) (77).

$\mathrm{nAChR}$ are present at essential regulatory sites and lead to multiple outcomes in sensitivity to exogenous stimuli or participation in neurodegeneration and inflammation. The presence of expressed $\mathrm{nAChR}$ in adipose tissue has provided additional research into the effects of nicotine on the body. It has shown that average smokers are skinnier and more likely to develop metabolic syndrome such as type II diabetes.

Also, patients with ulcerative colitis who stopped consuming tobacco developed more serious progression of the disease, i.e. nicotine had a protective effect. By contrast, patients with Crohn's disease improve disease severity if they smoke (78).

However, small concentrations of nicotine protect cells from damage induced by $\beta$-amyloids, inflammation, alcohol, hypoxia, but mechanism of action is unknown ( 40 , 79 , 80). High nicotine concentrations increase the number of nAChRs, due to desensitization instead of enhanced receptor function. Nicotine effects on $\mathrm{nAChR}$ are complex at molecular level and it is difficult to separate their consequences at system level (81).

\section{Neurodegenerative disorders}

The involvement of nicotinic receptors in many diseases, autoimmune responses and epilepsy, stimulated the development of $\mathrm{nAChR}$ subtypes of specific ligands as possible drugs (80). Reduced function and/or $\mathrm{nAChR}$ expression in the brain is associated with the pathophysiology of for example Alzheimer's disease (AD) or Parkinson's disease (PD), severe, incurable, degenerative brain disorders (40). Since the expression of the receptors cannot be induced easily, drug design for the treatment of neurodegenerative disorders is based on improving existing receptors' stimulation. One of the approaches is the use of nicotinic agonists or AChE inhibitors that are investigated to prevent present neurotransmitter acetylcholine from being degraded rapidly, which in turns enables activation of $\mathrm{nAChR}$ and the signal transmission to the next postsynaptic cell (82).

AD progression (Figure 3) leads to dementia, memory loss, thinking impairment, and changes in behaviour and personality. AD and other forms of dementia affect about 47 million people worldwide, in Croatia about 86,000 (83). The histopathology of the disease is well-known and is accompanied by a loss of cholinergic transmission, deposition of extracellular amyloid $\beta$-peptides $(\mathrm{A} \beta)$ in plaques, and hyperphosphorylation of $\tau$-protein leading to excessive formation of neurofibrillary tangles $(84,85)$. Also, receptor loss in Alzheimer's disease is much higher than in a normal aging brain $(86,87)$. Specifically, the degree of loss of $\alpha 4 \beta 2 \mathrm{nAChR}$ and $\alpha 7$-expressed expression are well correlated with the progressive range of cognitive decline in patients with mild to moderate $\mathrm{AD}$ (88). Two effects are important for cognitive improvement of $\mathrm{AD}$, improvement of synaptic transfer and reduction of neurodegeneration (89). Interestingly, $\alpha 4 \mathrm{nAChR}$ expression decreases by $80 \%$ in $\mathrm{AD}(90)$.

The simplest therapy to $\mathrm{nAChR}$ loss is the long-term use of nicotine (91) and in human clinical trials; nicotine alleviated AD symptoms (92). Additionally, nicotine has shown beneficial effects on learning, memory, attention, and cognitive functions in patients with AD. Now, the focus of the development of AD therapy is on specific nAChR agonists (Table 4), which should have low affinity for muscle nAChR to reduce unwanted muscle stimu-
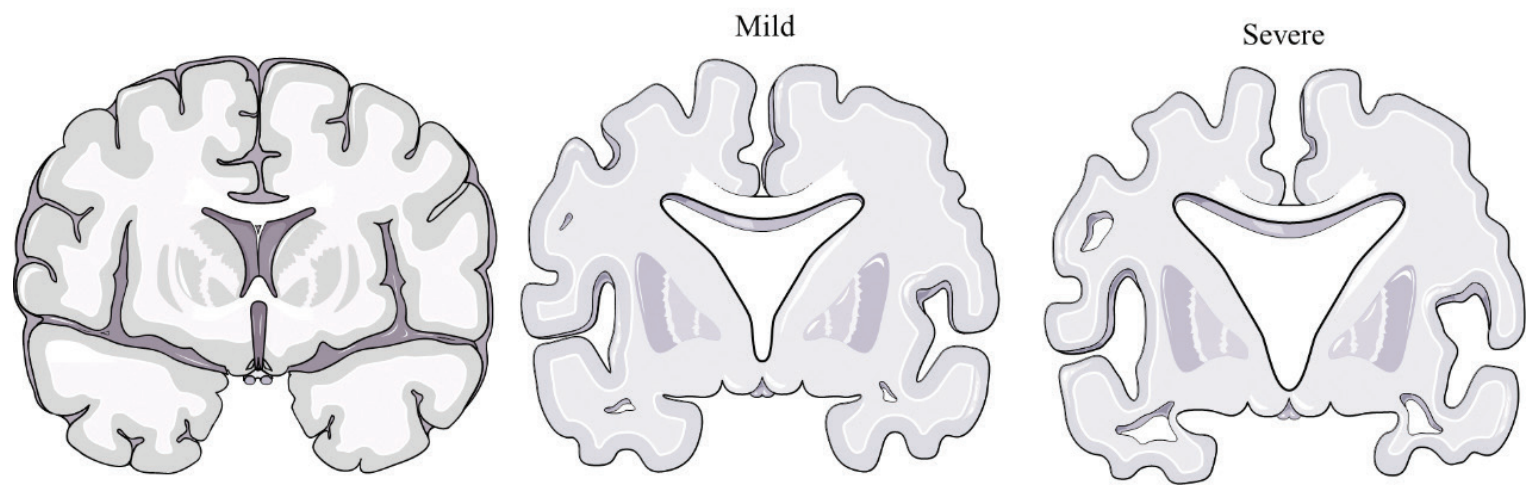

Figure 3. A sketch of the difference in the brain structure of the healthy brain and in patients with Alzheimer's disease (mild or severe) accompanied by severe cortical shrinkage (according to (99) and (100)). 
lation. Two types of receptors, $\alpha 7$ and $\alpha 4 \beta 2$, have become a target for AD treatment, since these receptors are expressed in the brain regions for memory and information processing. A crucial step in AD treatment could be the introduction of positive allosteric modulators (PAMs) to ensure multiple modulation of receptors to suppress disease (93), as well as a combination of drugs based on synergistic mechanisms. For example, a combination of galantamine that would inhibit AChE and modulate nAChRs, curcumine that would inhibit $\beta$-secretase and $\tau$-phosphorilation and rivastigmine to reversibly inhibit AChE; or a combination of tacrine, curcumine and huperzine A for the same reason (94). Five medications are currently used to treat the cognitive problems of $\mathrm{AD}$ : four are acetylcholinesterase inhibitors (tacrine (withdrawn due to toxicity (95)), rivastigmine, galantamine and donepezil) and the other (memantine) is an NMDA receptor antagonist. The way to increase the function of nAChR in the brain without nicotine is to sensitize receptors using allosteric potentiating ligands (APLs) that include drugs such as physostigmine and galantamine, one of the approved drugs for the treatment of AD (89). Second, noncompetitive agonists (NCAs) have agonistic activity and bind to a site close but still further than the ACh binding site on $\alpha$-subunits of nAChR (96). Although NCA encourages the opening of $\mathrm{nAChR}$ channels in many nerve and non-nerve cells, the likelihood of opening channels with such compounds is very low. Namely, galantamine acts as a nicotine NCA but not as a nicotine APL (97). Subunit $\alpha 7$ is the only nAChR subunit in mammals with positively charged residues within the $\alpha 118-140$ segment that is assumed to be an APL binding site (98).

Along with AD, Parkinson's disease (PD) is one of the most common neurodegenerative diseases in the world. It appears in all ethnic groups, in both sexes, although men are affected twice as much than women. The occurrence of illness increases with age and affects $1 \%$ of the population over 60 . Symptoms usually begin to appear for the first time between the age of 50 and 65 , but the disease may occur early in life, childhood or adolescence, albeit rarely. There are around 7-10 million people in the world suffering from Parkinson's disease, while in Croatia the number of registered people with the disease is 20,000 (122). Disease is caused by the degeneration of dopaminergic nerves of substantia nigra with symptoms of muscle stiffness, bradykinesia and blocking movement, loss of reflexes and tremors. Movement disorders are caused by a lack of dopamine-producing nerve cells, since dopamine is important in movement control. Current treatment for PD includes therapy with dopamine precursor L-DOPA (Figure 4), but neither does it stop the progression of the disease nor does its effectiveness last for a long time (123). nAChR-specific nicotine-based agonists are another direction in the development of therapy. One of the synthesized agonists, SIB-1765F, showed high affinity for $\alpha 4 \beta 2$, and was as equally effective as nicotine in stimulating
Table 4. Various known nicotinic agonists, antagonists and allosteric modulators

\begin{tabular}{|c|c|c|c|}
\hline Name & Action & Specific target & Refs. \\
\hline $\begin{array}{l}\text { 18-Methoxycoronaridine } \\
\text { (18-MC) }\end{array}$ & antagonist & $\alpha 3 \beta 4$ & $(101)$ \\
\hline A-582941 & agonist & $\alpha 7$ & $(102)$ \\
\hline $\mathrm{ABBF}$ & agonist & $\alpha 7$ & (103) \\
\hline ABT-089 & agonist & $\alpha 4 \beta 2$ & (104) \\
\hline ABT126a & agonist & $\alpha 7$ & (104) \\
\hline ABT- $418^{a}$ & agonist & $\alpha 4 \beta 2, \alpha 3 \beta 4$ & $(104)$ \\
\hline AR-R 17779 & agonist & $\alpha 7$ & $(105)$ \\
\hline Atropine ${ }^{\mathrm{b}}$ & antagonist & - & $(106)$ \\
\hline AVL-3288 & $\begin{array}{l}\text { allosteric } \\
\text { modulator }\end{array}$ & $\alpha 7$ & (107) \\
\hline Benthiactzine $^{b}$ & antagonist & $\alpha 7, \alpha 4 \beta 4, \alpha 4 \beta 2$ & $(108)$ \\
\hline CCMI & $\begin{array}{l}\text { allosteric } \\
\text { modulator }\end{array}$ & $\alpha 7$ & (104) \\
\hline $\begin{array}{l}\text { Dihydro- } \beta \text {-erythroidine } \\
(\mathrm{Dh} \beta \mathrm{E})\end{array}$ & antagonist & $\alpha 7, \alpha 3 \beta 4, \alpha 4 \beta 2$ & $(109)$ \\
\hline Dizocilpine (MK-801) & antagonist & $\alpha 7$ & (110) \\
\hline DMPP & agonist & - & (111) \\
\hline$d$-Tubocurarine (dTC) & antagonist & $\alpha 4 \beta 2, \alpha 7$ & $(112)$ \\
\hline Encenicline $^{a}$ (EVP-6124) & agonist & $\alpha 7$ & (113) \\
\hline GTS-21 & agonist & $\alpha 7$ & (104) \\
\hline Ibogaine & antagonist & $\alpha 3 \beta 4$ & (114) \\
\hline Ispronicline & agonist & $\alpha 4 \beta 2$ & (104) \\
\hline MB266 & antagonist & - & $(106)$ \\
\hline Memantine & antagonist & $\alpha 7$ & $(115)$ \\
\hline Metyllycaconitine (MLA) & antagonist & $\alpha 7$ & (116) \\
\hline NS-1738 & $\begin{array}{l}\text { allosteric } \\
\text { modulator }\end{array}$ & $\alpha 7$ & $(111)$ \\
\hline PNU-120596 & $\begin{array}{l}\text { allosteric } \\
\text { modulator }\end{array}$ & $\alpha 7$ & $(111)$ \\
\hline PNU-282987 & agonist & $\alpha 7$ & (117) \\
\hline $\mathrm{QNB}^{\mathrm{b}}$ & antagonist & - & $(106)$ \\
\hline Sazetidine & agonist & $\alpha 4 \beta 2$ & $(110)$ \\
\hline SEN123333 & agonist & $\alpha 7$ & (118) \\
\hline SSR-180711 & agonist & $\alpha 7$ & (119) \\
\hline Tropisetron & agonist & $\alpha 7$ & $(120)$ \\
\hline Vinblastine & antagonist & $\alpha 3 \beta 4$ & $(114)$ \\
\hline$\alpha$-bungarotoxin & antagonist & $\alpha 7$ & (121) \\
\hline
\end{tabular}

${ }^{a}$ in clinical trail phases $(104,107,113)$, b for organophosphorus poisoning treatment $(106,108)$

dopamine release. This agonist in combination with varenicline can attenuate brain overstimulation (124).

Other drugs that cause symptomatic relief and act by raising dopamine levels (L-DOPA, MAO-BI, COMT inhibitors), stimulating dopamine receptors (DA agonists), inhibiting cholinergic effects (anticholinergics) or inhibit- 


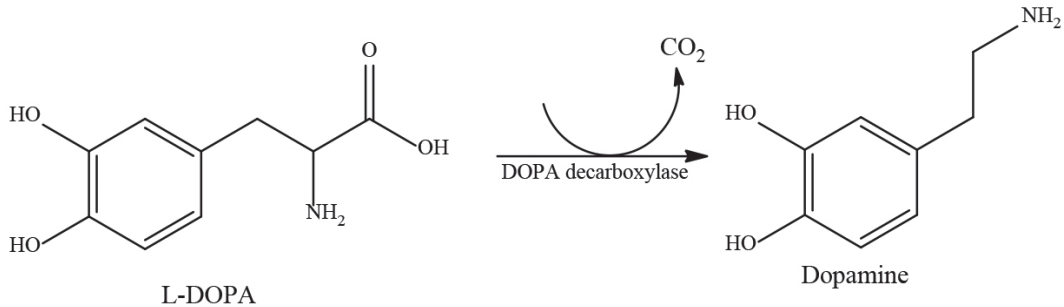

Figure 4. L-DOPA precursor structure and decarboxylation in dopamine in the organism (123).

ing glutaminergic NMDA receptors (amantadines). Thus, in such a system, L-DOPA replaces dopamine; COMT inhibitors maintain L-DOPA, which will metabolize and synthesize dopamine within the nerves, which can then be released into the synapse, MAO-B inhibitors serve to preserve existing dopamine and DA agonists mimic dopamine and bind to dopamine binding sites, as it is necessary to increase the dopamine concentration in PD patients. Interestingly, the $\alpha 6$ subtype was discovered in the substantia nigra and has become attractive as a pharmacological target for Parkinson's disease therapy (125). Epidemiological studies have shown that heavy smokers are less likely to have PD but also a whole spectrum of physiological changes are present in the function and expression of nAChR and desensitization (126). However, improvement of dopamine release was observed on rodents exposed to nicotine and degeneration of DA nerves was prevented $(57,127)$. The assumption is that nicotine mediates nerve protection because it prevents cell death, reduces symptoms, binds to $\mathrm{nAChR}$ and promotes expression of dopamine receptors in substantia nigra (128). The exact mechanism is not known yet, although nicotine effects are well explored.

Along with physiological changes, some studies suggest that DA and cholinergic systems operate in a dynamic balance, whose disturbance causes a variety of neurological disorders such as Parkinson's disease. DAdeficiency triggers a reduction in the efficacy of AChR, which result in increase in ACh release (129).

On the other side, an increased kinurenic acid (KYNA), the metabolite of tryptophan that is primarily produced in the brain and releases by astrocytes, follows neurodegenerative disorders and decreased activity/expression of $\mathrm{nAChR}$. Acting as an endogenous activity regulator of $\alpha 7 \mathrm{nAChR}$, KYNA can modulate synaptic transmission, synaptic plasticity, nerve endurance, and nervous connectivity in various brain regions (130).

\section{Organophosphorus compounds poisonings and $\mathbf{n A C h R s}$}

Organophosphorus compounds (OP) are a group of highly toxic xenobiotics used as pesticides, lubricants and oils for engines in the industry and as warfare nerve agents. The mechanism of their toxicity is the irreversible inhibition of the AChE, which participates in the regulation of nerve impulse transfer by hydrolising ACh (Figure 5). By chemical structure, OP compounds are esters, anhydrides or halides obtained by complete substitution of phosphorous, phosphonic and phosphinic acids. The base consists of a five-valent phosphorus atom coordinated by covalently bound oxygen or sulfur, and two different substituents (alkyl, aryl, alkoxy, alkylthio, aryloxy, mono- or dialkylamino) and the leaving group (fluorine, cyanide, etc.) (131).

Moshnin and Clermont synthesized the first OP compound, tetraethylpyrophosphate (TEPP). After some years, the potential of TEPP was recognized and it began being used as a pesticide. However, OP compounds showed to not be selective to species. During the Second World War, the toxic effects of OP compounds encouraged research and their use as chemical nerve agents. Soon, two series of nerve agents were developed: the Gseries (tabun, sarin, soman and cyclosarin), and V-series (like VX, from Venom, Victory or Viscous) $(37,132)$. In the 1990s, the production, stockpiling and use of chemical weapons was prohibited by Organisation for the Prohibition of Chemical Weapons (OPCW), and existing stocks were ordered to be destroyed. Since then, the use of nerve agents for research purposes has been strictly regulated. Still, the use of nerve agents has been recorded several times in recent years by terroristic groups attacking civilians (133).

As mentioned before in the text, when OP inhibits $\mathrm{AChE}$ in the nervous system, the neurotransmitter acetylcholine (ACh) accumulates in the synaptic cleft and over-stimulates cholinergic receptors, affecting the appearance of some specific symptoms. The effects of excessive activation of receptors are muscular weakness, cramps and tremor, hypertension and tachycardia, with additional effects such as headaches, memory disorders, wakefulness, confusion, loss of reflexes, anxiety, insomnia and respiratory depression and paralysis $(134,135)$. The main cause of the death of poisoned patients is the failure of the respiratory system. It is caused by paralysis of respiratory muscle, bronchoconstriction in combination with increased secretion and depression of the respiratory centre (136). Moreover, death can occur within minutes of exposure to nerve agents. Since OPs pass through the bloodbrain barrier, they also cause a number of other undesir- 


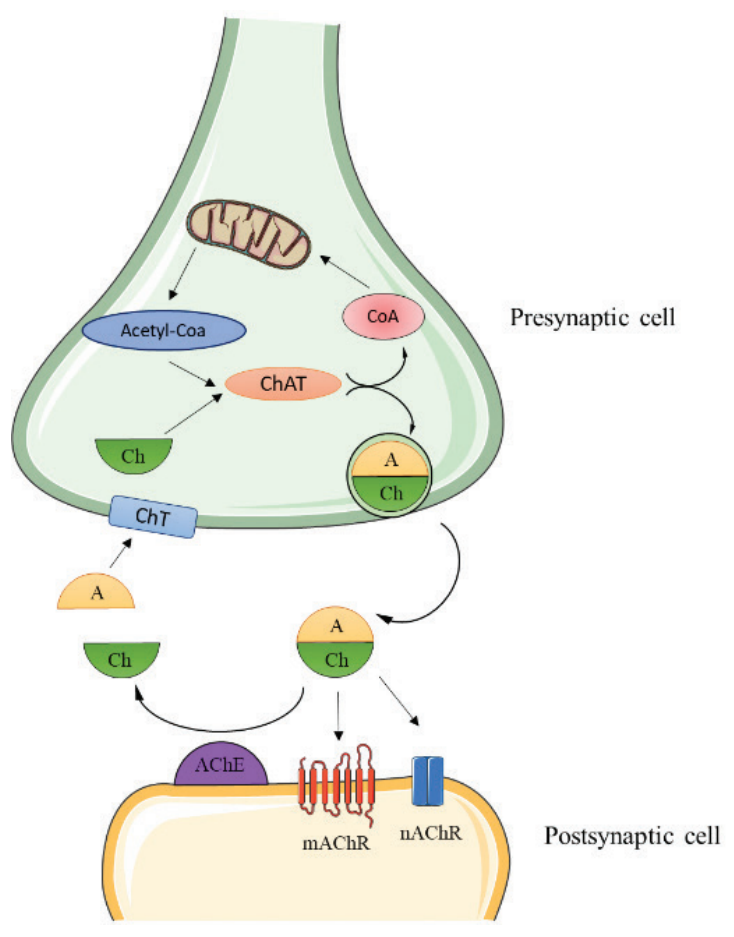

Figure 5. Synthesis of ACh in the synapse and association with receptors (according to (136))

able effects due to the action on receptors involved in the transmission of the impulse. Therapy for acute exposure to organophosphorus compounds is a combination of several different antidotes. Atropin is used as an antimuscarinic, ACh antagonist, which reduces the effects of $\mathrm{ACh}$ on muscarinic receptors. Compounds known as oximes are used as reactivators of inhibited AChE, which after reactivation reduces the concentration of accumulated acetylcholine in synaptic cleft. The third part of the therapy is administration of benzodiazepine to reduce convulsions and thus prevent brain damage (137). However, none of these drugs is effective enough and the effects of accumulated ACh overstimulating $\mathrm{nAChRs}$ persist.

There is ongoing research for selective $\mathrm{nAChR}$ inhibitors that could serve in therapy of OP poisonings. Scientists have tried different already available nicotinic antagonist drugs and ligands like $\delta$-tubocurarine (138). Furthermore, ketamine and similar drugs also have specific anticholinergic inhibitory activity on $\alpha 7$-nicotinic receptors and potentiated testing of a new group of compounds as drug candidates for clinical trials (139). In addition, procyclidine (an anticholinergic drug principally used for the treatment of drug-induced parkinsonism) has been shown to be an antimuscarin, antinicotinic and anti-NMDA receptor drug (140). Although many drugs are available to test from, the research in this field of nicotine antagonists application is still ongoing and none of the candidates has been introduced into medical practice of treating OP poisoning yet.

\section{Perspectives for future}

$\mathrm{nAChR}$ isolation paved the way for the design of new pharmacologically active compounds. As they co-operate with other receptors during different physiological processes, it is important to consider them in a wider picture as well. More specifically, the relationship, linkage and communication between different $\mathrm{nAChR}$ subtypes and other receptors should be investigated in the future research. In addition, we need to consider that understanding the role that $\mathrm{nAChR}$ plays in regulating immune responses inside and outside the central nervous system under normal physiological conditions. Furthermore, the development of ligands that selectively enhance the activity of a particular $n A C h R$ subtype is crucial for the future design of drugs for the treatment of, for example, neurodegenerative diseases and OP poisonings. At the same time, the application of such drugs should be as simple, effective and fast as possible to improve existing therapies. In this search, novel in silico, in vitro and in vivo models available for studies of potential agonists and antagonist of nicotinic receptors, could provide an essential platform.

Acknowledgments: this review was supported by the Croatian Science Foundation project UIP-2017-05-7260 to M.K. We are grateful to Makso Herman for language editing. Graphics from Servier Medical ART: SMART (https:// smart.servier.com/) were used for the figures.

\section{REFERENCES}

1. ALBUQUERQUE EX, PEREIRA EFR, ALKONDON M, ROGERS SW 2009 Mammalian Nicotinic Acetylcholine Receptors: From Structure to Function. Physiol Rev 89 (1): 73-120. https://doi.org/10.1152/physrev.00015.2008

2. CHANGEUX JP 2012 The Nicotinic Acetylcholine Receptor: The Founding Father of the Pentameric Ligand-gated Ion Channel Superfamily. J Biol Chem 287: 40207-40215.

https://doi.org/10.1074/jbc.R112.407668

3. STROUD RM, MCCARTHY MP, SHUSTER M 1990 Nicotinic acetylcholine receptor superfamily of ligand-gated ion channels. Biochemistry 29 (50): 11009-23. https://doi.org/10.1021/bi00502a001

4. GRUTTER T, DE CARVALHO LP, DUFRESNE V, TALY A, EDELSTEIN SJ, CHANGEUX JP 2005 Molecular tuning of fast gating in pentameric ligand-gated ion channels. Proc Natl Acad Sci USA 102 (50): 18207-18212. https://doi.org/10.1073/pnas.0509024102

5. KALAMIDA D, POULAS K, AVRAMOPOULOU V, FOSTIERI E, LAGOUMINTZIS G, LAZARIDIS K, SIDERI A, ZOURIDAKIS M, TZARTOS SJ 2007 Muscle and neuronal nicotinic acetylcholine receptors. Structure, function and pathogenicity. FEBS Journal 274: 3799-3845.

https://doi.org/10.1111/j.1742-4658.2007.05935.x

6. KING AM, AARON CK 2014 Organophosphate and carbamate poisoning. Emerg Med Clin North Am 33 (1): 133-51. https://doi.org/10.1016/j.emc.2014.09.010

7. LANGLEY JN 1905 On the reaction of cells and of nerve-endings to certain poisons, chiefly as regards the reaction of striated muscle to nicotine and to curare. J Physiol 33: 374-413. https://doi.org/10.1113/jphysiol.1905.sp001128 
8. NACHMANSOHN D 1961 Chemical factors controlling nerve activity. Science 134 (3494): 1962-8. https://doi.org/10.1126/science.134.3494.1962

9. CHANG CC, LEE CY 1963 Isolation of neurotoxins from the venom of Bungarus multicinctus and their modes of neuromuscular blocking action. Arch Int Pharmacodyn Ther 144: 241-257.

10. Cohen JB, Weber M, Huchet M, Changeux JP 1972 Purification from Torpedo marmorata electric tissue of membrane fragments particularly rich in cholinergic receptor protein. FEBS Lett 26 (1): 43-7. https://doi.org/10.1016/0014-5793(72)80538-6

11. CARTAUD J, BENEDETTI EL, COHEN JB, MEUNIER JC, CHANGEUX JP 1973 Presence of a lattice structure in membrane fragments rich in nicotinic receptor protein from the electric organ of Torpedo marmorata. FEBS Lett 33: 109-13. https://doi.org/10.1016/0014-5793(73)80171-1

12. HERTLING-JAWEED S, BANDININ G, MULLER-FAHROW A, DOMMES V, HUCHO F 1988 Rapid preparation of the nicotinic acetylcholine receptor for crystallization in detergent solution. FEBS Lett 241: 29-32. https://doi.org/10.1016/0014-5793(88)81024-x

13. PAAS Y, CARTAUD J, RECOUVREUR M, GRAILHE R, DUFRESNE V, PEBAY-PEYROYLA E, LANDAU EM, CHANGEUX JP 2003 Electron microscopic evidence for nucleation and growth of $3 \mathrm{D}$ acetylcholine receptor microcrystals in structured lipid-detergent matrices. Proc Natl Acad Sci USA 100: 11309-11314. https://doi.org/10.1073/pnas.1834451100

14. MCGEHEE DS, HEATH MJ, GELBER S, DEVAY P, ROLE LW 1995 Nicotine enhancement of fast excitatory synaptic transmission in CNS by presynaptic receptors. Science 269: 1692-1696 https://doi.org/10.1126/science. 7569895

15. FREEDMAN R, COON H, MYLES-WORSLEY M, ORR-URTREGER A, OLINCEY A 1997 Linkage of a neurophysiological deficit in schizophrenia to a chromosome 15 locus. Proc Natl Acad Sci USA 94: 587-592. https://doi.org/10.1073/pnas.94.2.587

16. WHITEHOUSE P, MATINO A, MARCUS K, ZWEIG R, SINGER H, PRICE D, KELLAR K 1988 Reduction in acetylcholine and nicotine binding in several degenerative diseases. Arch Neurol 45: 722-724. https://doi.org/10.1001/archneur.1988.00520310028012

17. PERRY E, MORRIS C, COURT J, CHENG A, FAIRBAIRN A, MCKEITH I, IRVING D, BROWN A, PERRY R 1995 Alteration in nicotine binding sites in Parkinson's disease, Lewy Body Dementia and Alzheimer's disease, possible index of early neuropathology. Neuroscience 64: 385-395. https://doi.org/10.1016/0306-4522(94)00410-7

18. SILVER A, SHYTLE R, PHILIP M, SANBERG P 1995 Transdermal nicotine in Tourette's syndrome. In: Clarke P, Quick M, Adelkofer F, Thurau K (ed) Effects of Nicotine on Biological Systems II. Birkhauser, Basel. https://doi.org/10.1007/978-3-0348-7445-8

19. SMULDERS CJGM, BUETERS TJH, VAILATIS, VAN KLEEF RGDM, VIJVERBERG HPM 2004 Block of neuronal nicotinic acetylcholine receptors by organophosphate insecticides. Toxicol Sci 82: 545-554. https://doi.org/ 10.1093/toxsci/kfh269

20. O'MALLEY M 1997 Clinical evaluation of pesticide exposure and poisonings. Lancet 349: 1161-1166. https://doi.org/ 10.1093/toxsci/kfh269

21. SOLBERG Y, BELKIN M 1997 The role of excitotoxicity in organophosphorous nerve agents central poisoning. Trends Pharmacol Sci 18: 183-185. https://doi.org/10.1016/s0165-6147(97)89540-5

22. ALUIGI MG, ANGELINI C, FALUGI C, FOSSA R, GENEVER P, GALLUS L, LAYER PG, PRESTIPINO G, RAKONCZAY Z, SGRO M, THIELECKE H, TROMBINO S 2005 Interaction between organophosphate compounds and cholinergic functions during development. Chem Biol Interact 157-158: 305-16. https://doi.org/10.1016/j.cbi.2005.10.037
23. KATZ EJ, CORTES VI, ELDEFRAWI ME, ELDEFRAWI AT 1997 Chlorpyrifos, parathion, and their oxons bind to and desensitize a nicotinic acetylcholine receptor: Relevance to their toxicities. Toxicol Appl Pharmacol 146: 227-236. https://doi.org/10.1006/taap.1997.8201

24. BAKRY NM, EL-RASHIDY AH, ELDEFRAWI AT, ELDEFRAWI ME 1988 Direct actions of organophosphate anticholinesterases on nicotinic and muscarinic acetylcholine receptors. J Biochem Toxicol 3: 235-259. https://doi.org/10.1002/jbt.2570030404

25. ELDEFRAWI ME, SCHWEIZER G, BAKRY NM, VALDES JJ 1988 Desensitization of the nicotinic acetylcholine receptor by diisopropylfluorophosphate. J Biochem Toxicol 3: 21-32. https://doi.org/ 10.1002/jbt.2570030104

26. RAO KS, ARACAVA Y, RICKETT DL, ALBUQUERQUE EX 1987 Noncompetitive blockade of the nicotinic acetylcholine receptor-ion channel complex by an irreversible cholinesterase inhibitor. J Pharmacol Exp Ther 240: 337-344.

27. TATTERSALL JE 1990 Effects of organophosphorus anticholinesterases on nicotinic receptor ion channels at adult mouse muscle endplates. Br J Pharmacol 101: 349-357. https://doi.org/10.1111/j.1476-5381.1990.tb12713.x

28. CAULFIELD MP, BIRDSALL NJM 1998 International Union of Pharmacology. XVII. Classification of Muscarinic Acetylcholine Receptors. Pharmacol Rev 50 (2): 279-290.

29. ZHANG H, LIUY, XU J, ZHANG F, LIANG Z, DU X, ZHANG H 2013 Membrane microdomain determines the specificity of 3 receptor-mediated modulation of Kv $7 / \mathrm{M}$ potassium currents. Neuroscience 254: 70-9. https://doi.org/10.1016/j.neuroscience.2013.08.064

30. HOLT JC, JORDAN PM, LYSAKOWSKI A, SHAH A, BARSZ K, CONTINI D 2017 Muscarinic acetylcholine receptors and Mcurrents underlie efferent-mediated slow excitation in calyx-bearing vestibular afferents. J Neurosci 37 (7): 1873-1887. https://doi.org/10.1523/JNEUROSCI.2322-16.2017

31. MALLOY CA, RITTER K, ROBINSON J, ENGLISH C, COOPER RL 2016 Pharmacological identification of cholinergic receptor subtypes on Drosophila melanogaster larval heart. J Comp Physiol B 186 (1): 45-57. https://doi.org/10.1007/s00360-015-0934-4

32. DI PINTO M, DI BARI R, MARTIN-ALVAREZ R, SPERDUTI $S$, SERRANO-ACEDO $S$, GATTA V, TATA AM, MENGOD G 2018 Comparative study of the expression of cholinergic system components in the CNS of experimental autoimmune encephalomyelitis mice: acute vs remitting phase. G. Eur J Neurosci 48 (5): 2165-2181. https://doi.org/10.1111/ejn.14125

33. WANG DW, ZHOU RB, YAO YM 2009 Role of cholinergic antiinflammatory pathway in regulating host response and its interventional strategy for inflammatory diseases. Chin J Traumatol 12 (6): 355-64. https://doi.org/10.3760/cma.j.issn.1008-1275.2009.06.007

34. KAWASHIMA K, FUJII T, MORIWAKI Y, MISAWA H, HORIGUCHI K 2012 Reconciling neuronally and nonneuronally derived acetylcholine in the regulation of immune function. Ann N Y Acad Sci 1261: 7-17. https://doi.org/10.1111/j.1749-6632.2012.06516.x

35. LORKE DE, PETROIANU GA 2018 Reversible cholinesterase inhibitors as pretreatment for exposure to organophosphates. A review. J Appl Toxicol 39 (1): 101-116. https://doi.org/10.1002/jat.3662

36. COSTA LG 2006 Current issue in organophosphate toxicology. Clin Chim Acta 366: 1-13. https://doi.org/10.1016/j.cca.2005.10.008

37. BAJGAR J, FUSEK J, KASSA J, KUČA K 2015 Global impact of chemical warfare agents used before and after 1945. In: Gupta RC (ed) Handbook of Toxicology of Chemical Warfare Agents, $2^{\text {nd }}$ ed. Academic Press, p 17-25. https://doi.org/10.1016/C2013-0-15402-5

38. UNWIN N 2013 Nicotinic acetylcholine receptor and the structural basis of neuromuscular transmission: insights from Torpedo 
postsynaptic membranes. Q Rev Biophys 46 (4): 283-322. https://doi.org/10.1017/S0033583513000061

39. FERREIRA-VIEIRA TH, GUIMARAES IM, SILVA FR, RIBEIRO FM 2016 Alzheimer's disease: Targeting the Cholinergic System. Curr Neuropharmacol 14 (1): 101-15. https://doi.org/10.2174/1570159x13666150716165726

40. BUCKINGHAM SD, JONES AK, BROWN LA, SATTELLE DB 2009 Nicotinic acetylcholine receptor signalling: roles in Alzheimer's disease and amyloid neuroprotection. Pharmacol Rev 61 (1): 39-61. https://doi.org/10.1124/pr.108.000562

41. PAPKE RL 2014 Merging old and new perspectives on nicotinic acetylcholine receptors. Biochem Pharmacol 89 (1): 1-11. https://doi.org/ 10.1016/j.bcp.2014.01.029

42. EXLEY R, CRAGG SJ 2008 Presynaptic nicotinic receptors: a dynamic and diverse cholinergic filter of striatal dopamine neurotransmission. Br J Pharmacol 153: S283-S297.

https://doi.org/10.1038/sj.bjp.0707510

43. WU J, ISHIKAWA M, ZHANG J, HASHIMOTO K 2010 Brain imaging of nicotinic receptors in Alzheimer's disease. Int J Alzheimers Dis 2010: 548913. https://doi.org/10.4061/2010/548913

44. GOTTI C, CLEMENTI F, FORNARI A, GAIMARRI A, GUIDUCCI S, MANFREDI I, MORETTI M, PEDRAZZI P, PUCCI L, ZOLI M 2009 Structural and functional diversity of native brain neuronal nicotinic receptors. Biochem Pharmacol 78 (7): 703-11. https://doi.org/ 10.1016/j.bcp.2009.05.024

45. PEREIRA EF, REINHARDT-MAELICKE S, SCHRATTENHOLZ A, MAELICKE A, ALBUQUERQUE EX 1993 Identification and functional characterization of a new agonist site on nicotinic acetylcholine receptors of cultured hippocampal neurons. J Pharmacol Exp Ther 265: 1474-1491.

46. SCHRATTENHOLZ A, COBAN T, SCHRODER B, OKONJO KO, KUHLMANN J, PEREIRA EFR, ALBUQUERQUE EX, MAELICKE A 1993 Biochemical characterization of a novel channel-activating site on nicotinic acetylcholine receptors. J Recept Res 13: 393-412.

47. DANI JA 2015 Neuronal Nicotinic Acetylcholine Receptor Structure and Function and Response to Nicotine. Int Rev Neurobiol 124: 3-19. https://doi.org/10.3109/10799899309073669

48. ZOLI M, PUCCI S, VILELLA A, GOTTI C 2018 Neuronal and extraneuronal nicotinic acetylcholine receptors. Curr Neuropharmacol 16 (4): 338-349. https://doi.org/10.2174/1570159X15666170912110450

49. MCKAY BE, PLACZEK AN, DANI JA 2007 Regulation of synaptic transmission and plasticity by neuronal nicotinic acetylcholine receptors. Biochem Pharmacol 74 (8): 1120-33. https://doi.org/10.1016/j.bcp.2007.07.001

50. KARLIN A 2002 Emerging structure of the nicotinic acetylcholine receptors. Nat Rev Neurosci 3: 102-114. https://doi.org/10.1038/nrn731

51. UNWIN N 2005 Refined structure of the nicotinic acetylcholine receptor at 4A resolution. J Mol Biol 346 (4): 967-89. https://doi.org/10.1016/j.jmb.2004.12.031

52. GREENBAUM L, LERER B 2009 Differential contribution of genetic variation in multiple brain nicotinic cholinergic receptors to nicotine dependence: recent progress and emerging open questions. Mol Psychiatry 14 (10):912-45. https://doi.org/10.1038/mp.2009.59

53. HURST R, ROLLEMA H, BERTRAND D Nicotinic acetylcholine receptors: from basic science to therapeutics. 2013 Pharmacol Ther 137 (1): 22-54.

https://doi.org/10.1016/j.pharmthera.2012.08.012

54. ENGEL AG, OHNO K, MILONE M, WANG HL, NAKANO $S$, BOUZAT C, PRUITT JN $2^{\text {ND }}$, HUTCHINSON DO, BRENGMAN JM, BREN N, SIEB JP, SINE SM 1996 New mutations in acetylcholine receptor subunit genes reveal heterogeneity in the slow-channel congenital myasthenic syndrome. Hum Mol Genet 5: 1217-1227. https://doi.org/10.1093/hmg/5.9.1217
55. ARIDON P, MARINI C, DI RESTA C, BRILLI E, DE FUSCO M, POLITI F, PARRINI E, MANFREDI I, PISANO T, PRUNA D, CURIA G, CIANCHETTI C, PASQUALETTI M, BECCHETTI A, GUERRINI R, CASARI G 2006 Increased sensitivity of the neuronal nicotinic receptor alpha 2 subunit causes familial epilepsy with nocturnal wandering and ictal fear. Am J Hum Genet 79: 342-350. https://doi.org/10.1086/506459

56. MICHALKA, STRICKER S, BECKER J, RUPPS R, PANTZAR T, MIERTUS J, BOTTA G, NARETTO VG, JANETZKI C, YAQOOB N, OTT CE, SEELOW D, WIECZOREK D, FIEBIG B, WIRTH B, HOOPMANN M, WALTHER M, KÖRBER F, BLANKENBURG M, MUNDLOS S, HELLER R, HOFFMANN K 2008 Acetylcholine receptor pathway mutations explain various fetal akinesia deformation sequence disorders. Am J Hum Genet 82: 464-476. https://doi.org/10.1016/j.ajhg.2007.11.006

57. QUIK M, BORDIA T, O'LEARY K 2007 Nicotinic receptors as CNS targets for Parkinson's disease. Biochem Pharmacol 74: 12241234. https://doi.org/10.1016/j.bcp.2007.06.01

58. KELSO ML, WEHNER JM, COLLINS AC, SCHEFF SW, PAULY JR 2006 The pathophysiology of traumatic brain injury in $\alpha 7$ nicotinic cholinergic receptor knockout mice. Brain Res 1083: 204-210. https://doi.org/10.1016/j.brainres.2006.01.127

59. BROIDE RS, LESLIE FM 1999 The $\alpha 7$ nicotinic acetylcholine receptor in neuronal plasticity. Mol Neurobiol 20: 1-16. https://doi.org/10.1007/BF02741361

60. MORLEY BJ, HAPPE HK 2000 Cholinergic receptors: dual roles in transduction and plasticity. Hear Res 147: 104-112. https://doi.org/10.1016/s0378-5955(00)00124-6

61. KHIROUG SS, HARKNESS PC, LAMB PW, SUDWEEKS SN, KHIROUG L, MILLAR NS, YAKEL JL 2002 Rat nicotinic ACh receptor $\alpha 7$ and $\beta 2$ subunits co-assemble to form functional heteromeric nicotinic receptor channels. J Physiol 540: 425-434. https://doi.org/10.1113/jphysiol.2001.013847

62. GOTTI C, ZOLI M, CLEMENTI F 2006 Brain nicotinic acetylcholine receptors: native subtypes and their relevance. Trends Pharmacol Sci 27 (9): 482-91. https://doi.org/10.1016/j.tips.2006.07.004

63. DUNCKLEY T, WU J, ZHAO L, LUKAS RJ 2003 Mutational analysis of roles for extracellular cysteine residues in the assembly and function of human $\alpha 7$-nicotinic acetylcholine receptors. Biochemistry 42: 870-876. https://doi.org/10.1021/bi020586x

64. WANAMAKER CP, CHRISTIANSON JC, GREEN WN 2003 Regulation of nicotinic acetylcholine receptor assembly. Ann NY Acad Sci 998: 66-80. https://doi.org/10.1196/annals.1254.009

65. CELIE PH, VAN ROSSUM-FIKKERT SE, VAN DIJK WJ, BREJC K, SMIT AB, SIXMA TK 2004 Nicotine and carbamylcholine binding to nicotinic acetylcholine receptors as studied in AChBP crystal structures. Neuron 41: 907-914. https://doi.org/10.1016/s0896-6273(04)00115-1

66. PENG X, GERZANICH V, ANAND R, WHITING PJ, LINDSTROM J 1994 Nicotine-induced increase in neuronal nicotinic receptors results from a decrease in the rate of receptor turnover. Mol Pharmacol 46: 523-530.

67. GREEN WN, WANAMAKER CP 1997 The role of the cystine loop in acetylcholine receptor assembly. J Biol Chem 272: $20945-$ 20953. https://doi.org/10.1074/jbc.272.33.20945

68. GEHLE VM, WALCOTT EC, NISHIZAKI T, SUMIKAWA K $1997 \mathrm{~N}$-glycosylation at the conserved sites ensures the expression of properly folded functional ACh receptors. Brain Res 45: 219-229. https://doi.org/10.1016/s0169-328x(96)00256-2

69. daCOSTA CJB, KAISER DE, BAENZIGER JE 2005 Role of glycosylation and membrane environment in nicotinic acetylcholine receptor stability. Biophys J 88 (3): 1755-64. https://doi.org/10.1529/ biophysj.104.052944

70. ROTH AF, WAN J, BAILEY AO, SUN B, KUCHAR JA, GREEN WN, PHINNEY BS, YATES JR III, DAVIS NG 2006 Global 
analysis of protein palmitoylation in yeast. Cell 125: 1003-1013. https://doi.org/10.1016/j.cell.2006.03.042

71. ALEXANDER JK, GOVIND AP, DRISDEL RC, BLANTON MP, VALLEJO Y, LAM TT, GREEN WN 2010 Palmitoylation of nicotinic acetylcholine receptors. J Mol Neurosci 40 (1-2): 12-20. https://doi.org/10.1007/s12031-009-9246-z

72. POLLOCK, VV, PASTOOR T, KATNIK C, CUEVAS J, WECKER L 2009 Cyclic AMP-dependent protein kinase A and protein kinase $\mathrm{C}$ phosphorylate $\alpha 4 \beta 2$ nicotinic receptor subunits at distinct stages of receptor formation and maturation. Neuroscience 158 : 1311-1325. https://doi.org/10.1016/j.neuroscience.2008.11.032

73. LAI A, PARAMESWARAN N, KHWAJA M, WHITEAKER P, LINDSTROM JM, FAN H, MCINTOSH JM, GRADY SR, QUIK M 2005 Long-term nicotine treatment decreases striatal $\alpha 6^{*}$ nicotinic acetylcholine receptor sites and function in mice. Mol Pharmacol 67: 1639-1647. https://doi.org/10.1124/mol.104.006429

74. DAJAS-BAILADOR FA, HEIMALA K, WONNACOTT S 2003 The allosteric potentiation of nicotinic acetylcholine receptors by galantamine is transduced into cellular responses in neurons: $\mathrm{Ca}^{2+}$ signals and neurotransmitter release. Mol Pharmacol 64: 12171226. https://doi.org/10.1124/mol.64.5.1217

75. FENSTER CP, WHITWORTH TL, SHEFFIELD EB, QUICK MW, LESTER RA 1999 Upregulation of surface alpha4beta2 nicotinic receptors is initiated by receptor desensitization after chronic exposure to nicotine. J Neurosci 19: 4804-4814. https://doi.org/10.1523/JNEUROSCI.19-12-04804.1999

76. HIREMAGALUR B, SABBAN EL 1995 Nicotine elicits changes in expression of adrenal catecholamine biosynthetic enzymes, neuropeptide $\mathrm{Y}$ and immediate early genes by injection but not continuous administration. Brain Res 32: 109-115. https://doi.org/10.1016/0169-328x(95)00068-4

77. DE JONGE WJ, VAN DER ZANDEN EP, THE FO, BIJLSMA MF, VAN WESTERLOO DJ, BENNINK RJ, BERTHOUD HR, UEMATSU S, AKIRA S, VAN DEN WIJNGAARD RM, BOECKXSTAENS GE. Stimulation of the vagus nerve attenuates macrophage activation by activating the Jak2-STAT3 signaling pathway. Nat Immunol 6: 844-851. https://doi.org/10.1038/ni1229

78. RUBIN DT, HANAUER SB 2000 Smoking and inflammatory bowel disease. Eur J Gastroenterol Hepatol 12: 855-862. https://doi.org/10.1097/00042737-200012080-00004

79. PARK HJ, LEE PH, AH NYW, CHOI YJ, LEE G, LEE DY, CHUNG ES, JIN BK 2007 Neuroprotective effect of nicotine on dopaminergic neurons by anti-inflammatory action. Eur J Neurosci 26: 79-89. https://doi.org/10.1111/j.1460-9568.2007.05636.x

80. BROWN D, RAMLOCHANSINGH C, MANAYE KF, TIZABI Y 2013 Nicotine promotes survival of cells expressing amyloid precursor protein and presenilin: implication for Alzheimer's disease. Neurosci Lett 535: 57-61. https://doi.org/10.1016/j.neulet.2012.12.046

81. SABBAGH MN, LUKAS RJ, SPARKS DL, REID RT 2002 The nicotinic acetylcholine receptor, smoking, and Alzheimer's disease. J Alzheimers Dis 4: 317-325. https://doi.org/10.3233/jad-2002-4407

82. POSADAS I, LÓPEZ-HERNÁNDEZ B, CEÑA V. 2013 Nicotinic receptors in neurodegeneration. Curr Neuropharmacol 11 (3): 298-314. https://doi.org/10.2174/1570159X11311030005

83. TAYLOR ME, CLOSE JCT 2018 Dementia. Handb Clin Neurol 159: 303-321. https://doi.org/10.1016/B978-0-444-63916-5.00019-7

84. KAR S, SLOWIKOWSKI SP, WESTAWAY D, MOUNT HT 2004 Interactions between beta-amyloid and central cholinergic neurons: implications for Alzheimer's disease. J Psychiatry Neurosci. 29 (6): 427-41.

85. ŠIMIĆ G, BABIĆ LEKO M, WRAY S, HARRINGTON C, DELALLE I, JOVANOV-MILOŠEVIĆ N, BAŽADONA D, BUÉE L, DE SILVA R, DI GIOVANNI G, WISCHIK C, HOF
PR. Tau protein hyperphosphorylation and aggregation in Alzheimer's disease and other tauopathies, and possible neuroprotective strategies. Biomolecules 6 (1): 6 . https://doi.org/10.3390/biom6010006

86. LOMBARDO S, MASKOS U 2014 Role of the nicotinic acetylcholine receptor in Alzheimer's disease pathology and treatment. Neuropharmacology 96 (Pt B): 255-62. https://doi.org/10.1016/j.neuropharm.2014.11.018

87. SHEN J, WU J 2015 Nicotinic Cholinergic Mechanisms in Alzheimer's Disease. Int Rev Neurobiol 124: 275-92. https://doi.org/10.1016/bs.irn.2015.08.002

88. AULD DS, KORNECOOK TJ, BASTIANETTO S, QUIRION R 2002 Alzheimer's disease and the basal forebrain cholinergic system: relations to $\beta$-amyloid peptides, cognition, treatment strategies. Prog Neurobiol 68: 209-245.

https://doi.org/10.1016/s0301-0082(02)00079-5

89. MAELICKE A, SCHRATTENHOLZ A, SAMOCHOCKI M, RADINA M, ALBUQUERQUE EX 2000 Allosterically potentiating ligands of nicotinic receptors as a treatment strategy for Alzheimer's disease. Behav Brain Res 113 (1-2): 199-206. https://doi.org/10.1016/s0166-4328(00)00214-x

90. MARTIN-RUIZ CM, COURT JA, MOLNAR E, LEE M, GOTTI C, MAMALAKI A, TSOULOUFIS T, TZARTOS S, BALLARD C, PERRY RH, PERRY EK $1999 \alpha 4$ but not $\alpha 3$ and $\alpha 7$ nicotinic acetylcholine receptor subunits are lost from the temporal cortex in Alzheimer's disease. J Neurochem 73: 1635-1640. https://doi.org/10.1046/j.1471-4159.1999.0731635.x

91. FUJII S, SUMIKAWA K 2001 Acute and chronic nicotine exposure reverse age-related declines in the induction of long-term potentiation in the rat hippocampus. Brain Res 894: 347-353. https://doi.org/10.1016/s0006-8993(01)02057-1

92. CROWE M, ANDEL R, PEDERSEN NL, JOHANSSON B, GATZ M 2003 Does participation in leisure activities lead to reduced risk of Alzheimer's disease? A prospective study of Swedish twins. J Gerontol B Psychol Sci Soc Sci 58: 249-255. https://doi.org/10.1093/geronb/58.5.p249

93. HAYDAR SN, DUNLOP J 2010 Neuronal Nicotinic Acetylcholine Receptors - Targets for the Development of Drugs to Treat Cognitive Impairment Associated with Schizophrenia and Alzheimer's Disease. Curr Top Med Chem 10: 140-152. https://doi.org/10.2174/156802610790410983

94. SAHOO AK, DANDAPAT J, DASH UC, KANHAR S 2018 Features and outcomes of drugs for combination therapy as multi-targets strategy to combat Alzheimer's disease. J Ethnopharmacol 215: 42-73. https://doi.org/10.1016/j.jep.2017.12.015

95. WATKINS PB, ZIMMERMAN HJ, KNAPP MJ, GRACON SI, LEWIS KW 1994 Hepatotoxic effects of tacrine administration in patients with Alzheimer's disease. JAMA 271: 992-998. https://doi.org/10.1001/jama.1994.03510370044030

96. PAPKE RL, TROCMÉ-THIBIERGE C, GUENDISCH D, AL RUBAIY SA, BLOOM SA 2011 Electrophysiological perspectives on the therapeutic use of nicotinic acetylcholine receptor partial agonists. J Pharmacol Exp Ther 337 (2): 367-79. https://doi.org/10.1124/jpet.110.177485

97. AKK G, STEINBACH, JH 2005 Galantamine activates muscletype nicotinic acetylcholine receptors without binding to the acetylcholinebinding site. J Neurosci 25: 1992-2001. https://doi.org/10.1523/JNEUROSCI.4985-04.2005

98. TARIOT PN, SCHNEIDER L, KATZ IR, MINTZER JE, STREET J, COPENHAVER M, WILLIAMS-HUGHES C 2006 Quetiapine treatment of psychosis associated with dementia: a double-blind, randomized, placebo controlled clinical trial. Am J Geriatr Psychiatry 14: 767-776. https://doi.org/10.1097/01.JGP.0000196628.12010.35

99. JOHNSON KA, FOX NC, SPERLING RA, KLUNK WE 2012 Brain imaging in Alzheimer disease. Cold Spring Harb Perspect Med 2 (4): a006213. https://doi.org/10.1101/cshperspect.a006213 
100. LEDIG C, SCHUH A, GUERRERO R, HECKEMANN RA, RUECKERT D 2018 Structural brain imaging in Alzheimer's disease and mild cognitive impairment: biomarker analysis and shared morphometry database. Sci Rep 8 (1): 11258. https://doi.org/10.1038/s41598-018-29295-9

101. GLICK SD, SELL EM, MCCALLUM SE, MAISONNEUVE IM 2011 Brain regions mediating $\alpha 3 \beta 4$ nicotinic antagonist effects of 18-MC on nicotine self-administration. Eur J Pharmacol 669 (1-3): 71-75. https://doi.org/10.1016/j.ejphar.2011.08.001

102. TIETJE KR, ANDERSON DJ, BITNER RS, BLOMME EA, BRACKEMEYER PJ, BRIGGS CA, BROWMAN KE, BURY D, CURZON P, DRESCHER KU, FROST JM, FRYER RM, FOX GB, GRONLIEN JH, HÅKERUD M, GUBBINS EJ, HALM S, HARRIS R, HELFRICH RJ, KOHLHAAS KL, LAW D, MALYSZ J, MARSH KC, MARTIN RL, MEYER MD, MOLESKY AL, NIKKEL AL, OTTE S, PAN L, PUTTFARCKEN PS, RADEK RJ, ROBB HM, SPIES E, THORIN-HAGENE K, WARING JF, WEEN H, XU H, GOPALAKRISHNAN M, BUNNELLE WH 2008 Preclinical characterization of A-582941: a novel alpha7 neuronal nicotinic receptor agonist with broad spectrum cognition-enhancing properties. CNS Neurosci Ther 14 (1): 65-82. https://doi.org/10.1111/j.1527-3458.2008.00037.x

103. BOESS FG, DE VRY J, ERB C, FLESSNER T, HENDRIX M, LUITHLE J, METHFESSEL C, RIEDL B, SCHNIZLER K, VAN DER STAAY F-J, VAN KAMPEN M, WIESE WB, KOENIG G 2007 The novel alpha7 nicotinic acetylcholine receptor agonist N-[(3R)-1-azabicyclo[2.2.2]oct-3-yl]-7-[2-(methoxy) phenyl]-1-benzofuran-2-carboxamide improves working and recognition memory in rodents. J Pharmacol Exp Ther 321 (2): 716 725. https://doi.org/10.1124/jpet.106.118976

104. BERTRAND D, TERRY AV Jr 2018 The wonderland of neuronal nicotinic acetylcholine receptors. Biochem Pharmacol 151: 214 225. https://doi.org/10.1016/j.bcp.2017.12.008

105. VAN KAMPEN M, SELBACH K, SCHNEIDER R, SCHIEGEL E, BOESS F, SCHREIBER R 2004 AR-R 17779 improves social recognition in rats by activation of nicotinic alpha7 receptors. Psychopharmacology (Berl) 172 (4):375-383. https://doi.org/10.1007/ s00213-003-1668-7

106. TIMPERLEY CM, BIRD M, GORE SJ, LINDSAY CD, RICE H, TATTERSALL JEH, WHITMORE CL, GREEN AC 2020 3 -Quinuclidinyl- $\alpha$-methoxydiphenylacetate: A multi-targeted ligand with antimuscarinic and antinicotinic effects designed for the treatment of anticholinesterase poisoning. Toxicol Lett 325: 67-76. https://doi.org/10.1016/j.toxlet.2020.01.027

107. GEE KW, OLINCY A, KANNER R, JOHNSON L, HOGENKAMP D, HARRIS J, TRAN M, EDMONDS SA, SAUER W, YOSHIMURA R, JOHNSTONE T, FREEDMAN R 2017 First in human trial of a type I positive allosteric modulator of alpha7nicotinic acetylcholine receptors: Pharmacokinetics, safety, and evidence for neurocognitive effect of AVL-3288. J Psychopharmacol 31 (4): 434-441. https://doi.org/10.1177/0269881117691590

108. LUO W, GEX, CUI W, WANG H 2018 Targeting cholinesterase inhibitor poisoning with a novel blocker against both nicotinic and muscarinic receptors. Neurotox Res 18 (2): 173-186. https://doi.org/10.1007/s12640-009-9119-9

109. CANNADY R, WEIR R, WEE B, GOTSCHLICH E, KOLIA N, LAU E, BROTHERTON J, LEVIN ED 2009 Nicotinic antagonist effects in the mediodorsal thalamic nucleus: regional heterogeneity of nicotinic receptor involvement in cognitive function. Biochem Pharmacol 78 (7): 788-794. https://doi.org/10.1016/j.bcp.2009.05.021

110. REZVANI AH, CAULEY M, SEXTON H, XIAO Y, BROWN ML, PAIGE MA, MCDOWELL BE, KELLAR KJ, LEVIN ED 2011 Sazetidine-A, a selective $\alpha 4 \beta 2$ nicotinic acetylcholine receptor ligand: effects on dizocilpine and scopolamine-induced attentional impairments in female Sprague-Dawley rats. Psychopharmacology (Berl) 215 (4): 620-630.

https://doi.org/10.1007/s00213-010-2161-8
111. FERREIRA-VIEIRA TH, GUIMARAES IM, SILVA FR, RIBEIRO FM 2016 Alzheimer's disease: targeting the cholinergic system. Curr Neuropharmacol 14 (1): 101-115. https://doi.org/10.2174/1570159x13666150716165726

112. FELIX R, LEVIN ED 1997 Nicotinic antagonist administration into the ventral hippocampus and spatial working memory in rats. Neuroscience 81 (4): 1009-1017.

https://doi.org/10.1016/s0306-4522(97)00224-8

113. PRICKAERTS J, VAN GOETHEM NP, CHESWORTH R, SHAPIRO G, BOESS FG, METHFESSEL C, RENEERKENS OAH, FLOOD DG, HILT D, GAWRYL M, BERTRAND S, BERTRAND D, KÖNIG G 2012 EVP-6124, a novel and selective $\alpha 7$ nicotinic acetylcholine receptor partial agonist, improves memory performance by potentiating the acetylcholine response of $\alpha 7$ nicotinic acetylcholine receptors. Neuropharmacology 62 (2): 1099-1110. https://doi.org/10.1016/j.neuropharm.2011.10.024

114. ARIAS HR, FEUERBACH D, TARGOWSKA-DUDA KM, JOZWIAK K 2010 Catharanthine alkaloids are noncompetitive antagonists of muscle-type nicotinic acetylcholine receptors. Neurochem Int 57(2): 153-161. https://doi.org/10.1016/j.neuint.2010.05.007

115. ROGAWSKI MA, WENK GL 2003 The neuropharmacological basis for the use of memantine in the treatment of Alzheimer's disease. CNS Drug Rev 9 (3): 275-308.

https://doi.org/10.1111/j.1527-3458.2003.tb00254.x

116. CANNADY R, WEIR R, WEE B, GOTSCHLICH E, KOLIA N, LAU E, BROTHERTON J, LEVIN ED 2009 Nicotinic antagonist effects in the mediodorsal thalamic nucleus: regional heterogeneity of nicotinic receptor involvement in cognitive function. Biochem Pharmacol 78 (7): 788-794. https://doi.org/10.1016/j.bcp.2009.05.021

117. HAJÓS M, HURST RS, HOFFMANN WE, KRAUSE M, WALL TM, HIGDON NR, GROPPI VE 2005 The selective alpha7 nicotinic acetylcholine receptor agonist PNU-282987 [N[(3R)-1-Azabicyclo[2.2.2]oct-3-yl]-4-chlorobenzamide hydrochloride] enhances GABAergic synaptic activity in brain slices and restores auditory gating deficits in anesthetized rats. J Pharmacol Exp Ther 312 (3): 1213-1222. https://doi.org/10.1124/jpet.104.076968

118. RONCARATI R, SCALI C, COMERYTA, GRAUER SM, ASCHMI S, BOTHMANN H, JOW B, KOWAL D, GIANFRIDDO M, KELLEY C, ZANELLI U, GHIRON C, HAYDAR S, DUNLOP J, TERSTAPPEN GC 2009 Procognitive and neuroprotective activity of a novel alpha7 nicotinic acetylcholine receptor agonist for treatment of neurodegenerative and cognitive disorders. J Pharmacol Exp Ther 329 (2): 459-468. https://doi.org/10.1124/jpet.108.150094

119. PICHAT P, BERGIS OE, TERRANOVA JP, URANI A, DUARTEC, SANTUCCI V, GUEUDET C, VOLTZ C, STEINBERG R, STEMMELIN J, OURY-DONAT F, AVENET P, GRIEBEL G, SCATTON B 2007 SSR180711, a novel selective alpha7 nicotinic receptor partial agonist: (II) efficacy in experimental models predictive of activity against cognitive symptoms of schizophrenia. Neuropsychopharmacology 32 (1): 17-34. https://doi.org/10.1038/sj.npp.1301188

120. CALLAHAN PM, BERTRAND D, BERTRAND $S$, PLAGENHOEF MR, TERRY AV Jr 2017 Tropisetron sensitizes $\alpha 7$ containing nicotinic receptors to low levels of acetylcholine in vitro and improves memory-related task performance in young and aged animals. Neuropharmacology 117: 422-433. https://doi.org/10.1016/j.neuropharm.2017.02.025

121. MOORE MA, MCCARTHY MP 1995 Snake venom toxins, unlike smaller antagonists, appear to stabilize a resting state conformation of the nicotinic acetylcholine receptor. Biochim Biophys Acta 1235 (2): 336-342. https://doi.org/10.1016/0005-2736(95)80022-8

122. STAUDT MD, DI SEBASTIANO AR, XU H, JOG M, SCHMID S, FOSTER P, HEBB MO 2016 Advances in Neuro- 
trophic Factor and Cell-Based Therapies for Parkinson's Disease: A Mini-Review. Gerontology 62 (3): 371-380. https://doi.org/10.1159/000438701

123. WHITFIELD AC, MOORE BT, DANIELS RN 2014 Classics in chemical neuroscience: levodopa. ACS Chem Neurosci 5 (12): 1192-7. https://doi.org/10.1021/cn5001759

124. SPILLER K, XI ZX, LI X, ASHBY CR JR, CALLAHAN PM, TEHIM A, GARDNER EL 2009 Varenicline attenuates nicotineenhanced brain-stimulation reward by activation of alpha4beta2 nicotinic receptors in rats. Neuropharmacology 57 (1): 60-6. https://doi.org/10.1016/j.neuropharm.2009.04.006

125. Haddad F, Sawalha M, Khawaja Y, Najjar A, Karaman R 2017 Dopamine and levodopa prodrugs for the treatment of Parkinson's disease. Molecules 23 (1): pii: E40.

https://doi.org/10.3390/molecules 23010040

126. COLLINS AC, MARKS MJ 1991 Progress towards the development of animal models of smoking-related behaviors. J Addict Dis 10: 109-126. https://doi.org/10.1300/J069v10n01_08

127. QUIK M 2004 Smoking, nicotine and Parkinson's disease. Trends Neurosci 27: 561-568. https://doi.org/10.1016/j.tins.2004.06.008

128. RYAN RE, ROSS SA, DRAGO J, LOIACONO RE 2001 Doserelated neuroprotective effects of chronic nicotine in 6-hydroxydopamine treated rats, and loss of neuro-protection in $\alpha 4$ nicotinic receptor subunit knockout mice. Br J Pharmacol 132: 1650-1656. https://doi.org/10.1038/sj.bjp.0703989

129. LESTER DB, ROGERS TD, BLAHA CD 2010 Acetylcholinedopamine interactions in the pathophysiology and treatment of CNS disorders. CNS Neurosci Ther 16 (3): 137-162. https://doi.org/10.1111/j.1755-5949.2010.00142.x

130. KISS C, CERESOLI-BORRONI G, GUIDETTI P, ZIELKE CL, ZIELKE HR, SCHWARCZ R 2003 Kynurenate production by cultured human astrocytes. J Neural Transm 110: 1-14. https://doi.org/10.1007/s00702-002-0770-z

131. BOSAK A 2006 Organofosforni spojevi: klasifikacija i reakcije s enzimima. Arh Hig Rada Toksikol 57: 445-57.

132. VALE JA, MARRS TC OBE, MAYNARD RL CBE 2018 Novichok: a murderous nerve agent attack in the UK. Clin Toxicol (Phila) 14: 1-5. https://doi.org/10.1080/15563650.2018.1469759
133. VOICU V, BAJGAR J, MEDVEDOVICI A, RADULESCU FS, MIRON DS 2010 Pharmacokinetics and pharmacodynamics of some oximes and associated therapeutic consequences: A critical review. J Appl Toxicol 30 (8): 719-29. https://doi.org/10.1002/jat.1561

134. MYHRER T, PÅL A 2015 Prophylactic and therapeutic measures in nerve agent poisoning. In: Gupta RC (ed) Handbook of Toxicology of Chemical Warfare Agents, $2^{\text {nd }}$ ed. Academic Press, p 9891001. https://doi.org/10.1016/C2013-0-15402-5

135. JOHN H, BALZUWEIT F, KEHE K, WOREK F, THIERMANN H 2015 Toxicokinetic aspects of nerve agents and vesicants. In: Gupta RC (ed) Handbook of Toxicology of Chemical Warfare Agents, $2^{\text {nd }}$ ed. Academic Press, p 817-856. https://doi.org/10.1016/C2013-0-15402-5

136. GUPTA RC 2015 Introduction. In: Gupta RC (ed) Handbook of Toxicology of Chemical Warfare Agents, $2^{\text {nd }}$ ed. Academic Press, p 3-5. https://doi.org/10.1016/C2013-0-15402-5

137. WESTFALL TC, WESTFALL DP 2006 Neurotransmission: The autonomic and somatic motor nervous systems. In: Brunton LL, Lazo IS, Parker KL (ed) Goodman and Gilman's the Pharmacological Basis of Therapeutics, $11^{\text {th }}$ ed. New York: McGraw-Hill, p 137-182. https://doi.org/10.1021/jm058286b

138. PEREIRA DM, FERRERES F, OLIVEIRA JM, GASPAR L, FARIA J, VALENTÃO P, SOTTOMAYOR M, ANDRADE PB 2010 Pharmacological effects of Cath ${ }^{a}$ ranthus roseus root alkaloids in acetylcholinesterase inhibition and cholinergic neurotransmission. Phytomedicine. 17 (8-9): 646-52. https://doi.org/10.1016/j.phymed.2009.10.008

139. MOADDEL R, ABDRAKHMANOVA G, KOZAK J, JOZWIAK K, TOLL L, JIMENEZ L, ROSENBERG A, TRAN T, XIAO Y, ZARATE CA, WAINER IW 2013 Sub-anesthetic concentrations of $(R, S)$-ketamine metabolites inhibit acetylcholine-evoked currents in $\alpha 7$ nicotinic acetylcholine receptors. Eur J Pharmacol 698 (1-3): 228-34. https://doi.org/10.1016/j.ejphar.2012.11.023

140. KIM YB, CHEON KC, HU GH 2002 Effects of combinational prophylactics composed of physostigmine and procyclidine on soman-induced lethality, seizures and brain injuries. Env Toxicol Pharmacol 11: 15-21.

https://doi.org/10.1016/s1382-6689(01)00096-5 